\title{
Influence of Gamma Irradiation on Flowering of Gladiolus (Gladiolus hybrida L.)
}

\author{
Kuldeep Sahariya, R.A. Kaushik, Rashid Khan" and Deepak Sarolia
}

Rajasthan College of Agriculture, MPUAT Udaipur-313001, Rajasthan, India

*Corresponding author

\begin{abstract}
A B S T R A C T
Keywords

Gamma radiations, Gladiolus hybrida L, Sprouting and flowering.

Article Info

Accepted:

12 September 2017

Available Online:

10 November 2017

Influence of gamma irradiations was studied in ten varieties of gladiolus (Gladiolus hybrida L.) namely, Candyman Rose, American Beauty, Chandni, Red beauty, Punjab Morning, White Prosperity, Jester, Srijana, Psittacinous Hybrid and Priscilla were irradiated with 0.5, 1.0, 1.5, 2.0, 2.5, 3.0, 3.5, 4.0, 4.5 and 5.0 $\mathrm{kR}$ doses. Earliest sprouting was recorded in $3.0 \mathrm{kr}$ gamma treatment. Higher doses of gamma irradiation show lethal effect on various vegetative and floral traits. Maximum number of days taken to spike emergence was recorded with 3.5 $\mathrm{kr}$ dose of gamma irradiation. Earliest flowering was recorded with interaction of control with cv. Candyman Rose. Number of florets per spike reduced due to application of gamma doses, as doses increased and higher doses of gamma rays resulted in minimum number of florets per spike. Radiation treatments at higher doses caused delayed in spike initiation with decrease in spike length, number and size of florets.
\end{abstract}

\section{Introduction}

Among the commercial flowers, gladiolus is one of the most important flowers in India because of its majestic spikes containing attractive, elegant and delicate florets of various shades, sequential opening of flowers for a longer duration and good keeping quality of cut spikes (Singh, 2006). The demand of gladiolus is increasing therefore; it needs attention towards genetic improvement. These have mostly been evolved through conventional breeding but a few through mutation breeding. Mutations are induced in different crops to create variability for further improvement. In vegetatively propagated plants, mutation breeding offers great potentialities as the mutated part can be conveniently perpetuated by vegetative means resulting in the development of new forms. Gladiolus is highly heterozygous in its genetic constitution which makes it promising test material for inducing physical mutagenesis.

The effects of gamma rays on gladiolus have been studied by several workers but very few varieties have been developed through gamma radiations. Hence, in the present investigation, emphasis was laid on finding out variations caused by gamma radiations in morphological characters including colour variations. An attempt was made to develop a variety by fixing the induced variation in succeeding generations. 


\section{Materials and Methods}

The present experiment was carried out was at Horticulture farm, Rajasthan College of Agriculture, Udaipur (Rajasthan) during 2013-2014 and 2014-2015. The dormant corms (3.5 to $4.5 \mathrm{~cm}$ diameter) of ten commercial varieties of gladiolus viz., Candyman Rose, American Beauty, Chandni, Red beauty, Punjab Morning, White Prosperity, Jester, Srijana, Psittacinous Hybrid and Priscilla were subjected to gamma radiations. The corms were treated with eleven doses of gamma radiations viz $0.5,1.0$, $1.5,2.0,2.5,3.0,3.5,4.0,4.5$ and $5.0 \mathrm{kR}$ along with control (without treatment).

The corms were planted in the field within 24 hours of treatment in Randomized Block Design with Factorial Concept (Panse and Sukhatme, 1967). Data were recorded in vM1 and vM2 generation on different flowering parameters.

\section{Results and Discussion}

Various doses of gamma rays exhibited significantly effect on sprouting of gladiolus corms (Table 1). Earliest sprouting was recorded in $3.0 \mathrm{kr}$ gamma treatment followed by control (untreated) and $1.5 \mathrm{kr}$ gamma treatment. Whereas, maximum days to sprouting was recorded with $5.0 \mathrm{kr}(16.56$ days) which was at par with gamma doses of $2.5 \mathrm{kr}, 4.5 \mathrm{kr}, 1.0 \mathrm{kr}$ and $2.0 \mathrm{kr}$ during first year. Pronounced effect of gamma irradiation treatments were observed during second year. Higher doses of gamma irradiation show lethal effect on sprouting of corms of some varieties results in no sprouting. In cultivar Psittacinous Hybrid corms were not sprouted at $2.5 \mathrm{kr}, 3.0 \mathrm{kr}, 3.5, \mathrm{kr}, 4.0 \mathrm{kr}, 4.5 \mathrm{kr}$ and 5.0 $\mathrm{kr}$ dose of gamma irradiation. Dose $5.0 \mathrm{kr}$ exhibited lethal effect on cvs. Chandni, Punjab Morning, Jester, Srijina and Psittacinous Hybrid however normal sprouting was observed in other cultivars. 4.5 $\mathrm{kr}$ dose showed lethal effect on cvs. Psittacinous Hybrid, Punjab Morning and Chandni whereas $4.0 \mathrm{kr}$ dose also showed lethal effect on cv. Punjab Morning. This early sprouting of gladiolus corms at lower dose of gamma rays was probably related with the increase in the activities of gibberellins and auxins and disappearance of inhibitors. Misra and Bajpai (1983), Awad and Elbahr (1986), Pranom et al., (1986) and Karki and Srivastava (2010) also observed similar finding in slight earliness in sprouting of gladiolus corms when treated with lower doses of gamma rays. Patil et al., (2009) and Patil et al., (2014) reported that most of the characters were stimulated till $3.00 \mathrm{kr}$ treatment and started to reduce on higher dose but treatment $2.00 \mathrm{kr}$ has proved better treatment including control. Low level of mutagen itself is not responsible for early sprouting of gladiolus but it influences the activity of enzymes. Enzymes play an important role in plant metabolism to accelerate metabolism activities and consequently result in stimulating plant growth (Misra and Bajpai, 1983).

Days to spike emergence was influenced significantly due to gamma irradiation treatment and varieties during both the years of investigation (Table 2). Some varieties did not show any sprouting resulted in no spike emergence during both years. Gamma doses at $4.0 \mathrm{kr}, 4.5 \mathrm{kr}$ and $5.0 \mathrm{kr}$ were found lethal in case of cv. Punjab Morning and Psittacinous Hybrid while cv. Chandni failed to produce any spike at $4.5 \mathrm{kr}$ and $5.0 \mathrm{kr}$ treatment during 1st year. Maximum number of days taken to spike emergence was recorded with $3.5 \mathrm{kr}$ dose of gamma irradiation followed by $1.5 \mathrm{kr}, 1.0 \mathrm{kr}, 2.0 \mathrm{kr}$ and $0.5 \mathrm{kr}$. Earliest spike emergence was recorded with interaction of $5.0 \mathrm{kr}$ with $\mathrm{cv}$. Candyman Rose during both years of investigation. 
Table.1 Effect of gamma irradiation on days to sprouting in different varieties of gladiolus

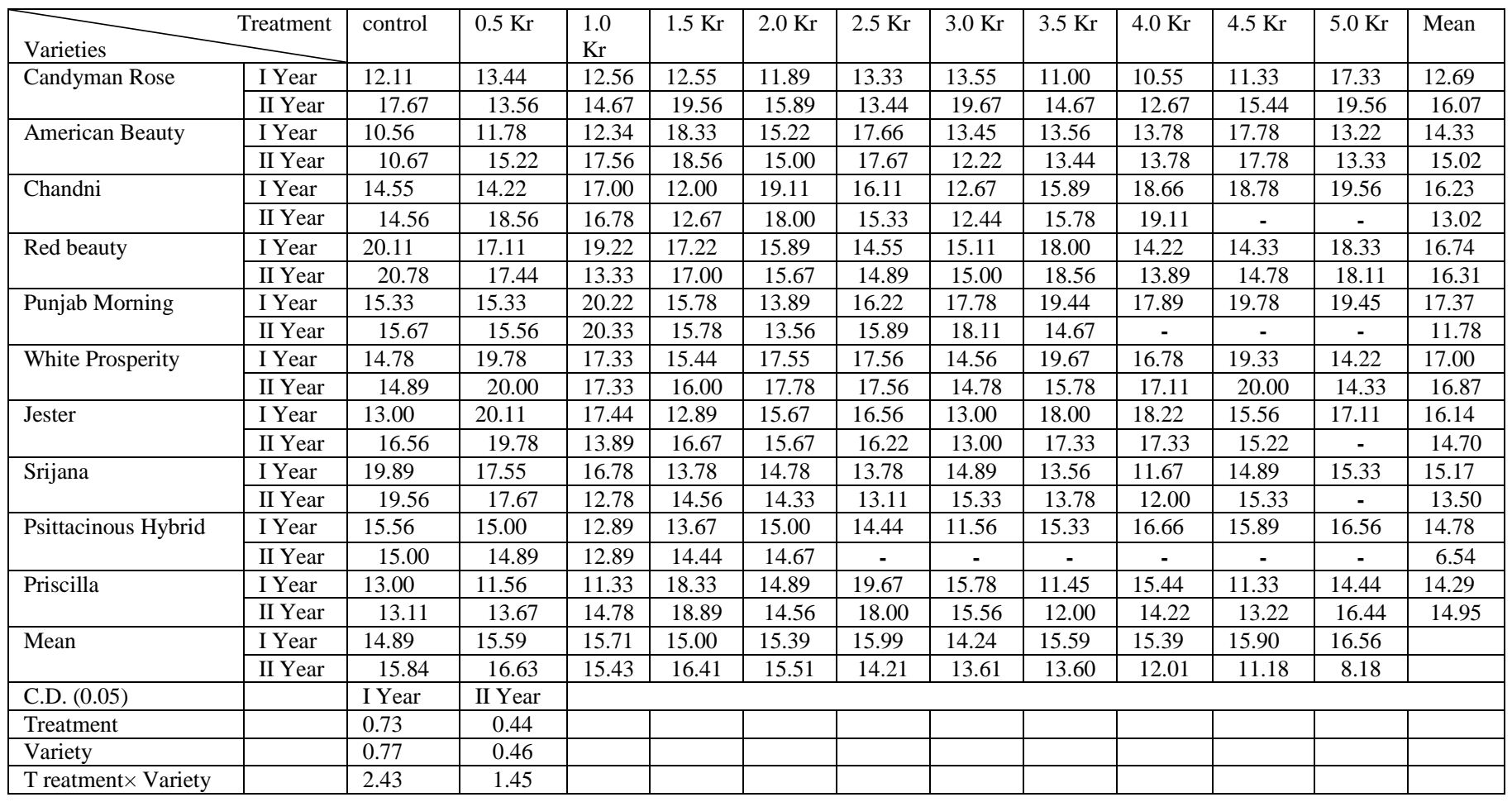

Table.2 Effect of gamma irradiation on days taken to spike emergence in different varieties of gladiolus

\begin{tabular}{|c|c|c|c|c|c|c|c|c|c|c|c|c|c|}
\hline Varieties & rreatment & control & $0.5 \mathrm{Kr}$ & $\begin{array}{l}1.0 \\
\mathrm{Kr}\end{array}$ & $1.5 \mathrm{Kr}$ & $2.0 \mathrm{Kr}$ & $2.5 \mathrm{Kr}$ & $3.0 \mathrm{Kr}$ & $3.5 \mathrm{Kr}$ & $4.0 \mathrm{Kr}$ & $4.5 \mathrm{Kr}$ & $5.0 \mathrm{Kr}$ & Mean \\
\hline \multirow[t]{2}{*}{ Candyman Rose } & I Year & 64.44 & 65.00 & 72.22 & 97.89 & 71.22 & 83.00 & 86.33 & 71.78 & 64.89 & 87.22 & 63.33 & 75.21 \\
\hline & II Year & 64.89 & 66.11 & 72.00 & 97.11 & 71.00 & 81.78 & 86.22 & 71.33 & 64.78 & 87.00 & 62.67 & 74.99 \\
\hline American Beauty & II Year & 66.89 & 72.56 & 98.78 & 72.44 & 84.67 & 87.45 & 66.44 & 70.89 & 98.33 & 65.22 & 66.56 & 77.29 \\
\hline \multirow[t]{2}{*}{ Chandni } & I Year & 66.67 & 95.00 & 66.34 & 87.22 & 98.44 & 66.56 & 66.00 & 87.22 & 65.89 & - & - & 63.58 \\
\hline & II Year & 67.33 & 96.33 & 66.89 & 87.22 & 98.22 & 66.89 & 65.45 & 87.22 & 65.67 & - & - & 63.75 \\
\hline \multirow[t]{2}{*}{ Punjab Morning } & I Year & 66.00 & 86.56 & 98.89 & 66.00 & 67.45 & 86.56 & 67.11 & 66.89 & - & - & - & 55.04 \\
\hline & II Year & 66.00 & 86.55 & 98.89 & 66.00 & 67.44 & 86.55 & 66.22 & 66.78 & - & - & - & 54.95 \\
\hline \multirow[t]{2}{*}{ White Prosperity } & I Year & 86.56 & 98.67 & 66.33 & 66.89 & 86.56 & 67.56 & 66.67 & 67.45 & 97.78 & 66.33 & 86.11 & 77.90 \\
\hline & II Year & 86.78 & 98.66 & 66.67 & 66.78 & 86.78 & 67.33 & 66.67 & 67.22 & 97.89 & 66.33 & 86.44 & 77.96 \\
\hline \multirow[t]{2}{*}{ Jester } & I Year & 97.45 & 66.56 & 66.78 & 86.55 & 68.67 & 67.33 & 66.11 & 97.45 & 65.67 & 86.22 & 98.78 & 78.87 \\
\hline & II Year & 98.56 & 66.33 & 66.67 & 86.44 & 68.67 & 67.33 & 66.11 & 97.45 & 65.67 & 86.22 & - & 69.95 \\
\hline Srijana & I Year & 65.67 & 67.33 & 86.22 & 68.00 & 67.00 & 66.67 & 97.67 & 66.00 & 86.33 & 98.67 & 66.00 & 75.96 \\
\hline Priscilla & II Year & 86.00 & 68.00 & 67.00 & 66.67 & 97.67 & 66.00 & 86.33 & 98.67 & 66.00 & 67.00 & 86.33 & 77.79 \\
\hline \multirow[t]{2}{*}{ Mean } & I Year & 76.29 & 77.22 & 77.80 & 77.80 & 77.29 & 75.42 & 75.51 & 77.95 & 61.26 & 53.81 & 56.33 & \\
\hline & II Year & 76.60 & 77.62 & 78.09 & 77.60 & 77.36 & 65.66 & 68.93 & 69.38 & 61.23 & 53.67 & 39.77 & \\
\hline C.D. (0.05) & & I Year & II Year & & & & & & & & & & \\
\hline Treatment & & 0.42 & 0.56 & & & & & & & & & & \\
\hline Variety & & 0.44 & 0.59 & & & & & & & & & & \\
\hline T reatment $\times$ Variety & & 1.38 & 1.85 & & & & & & & & & & \\
\hline
\end{tabular}


Table.3 Effect of gamma irradiation on days taken to flowering in different varieties of gladiolus

\begin{tabular}{|c|c|c|c|c|c|c|c|c|c|c|c|c|c|}
\hline Varieties & reatment & control & $0.5 \mathrm{Kr}$ & $1.0 \mathrm{Kr}$ & $1.5 \mathrm{Kr}$ & $2.0 \mathrm{Kr}$ & $2.5 \mathrm{Kr}$ & $3.0 \mathrm{Kr}$ & $3.5 \mathrm{Kr}$ & $4.0 \mathrm{Kr}$ & $4.5 \mathrm{Kr}$ & $5.0 \mathrm{Kr}$ & Mean \\
\hline \multirow[t]{2}{*}{ Candyman Rose } & I Year & 69.44 & 73.89 & 77.67 & 102.89 & 76.11 & 88.78 & 90.89 & 78.22 & 70.22 & 91.67 & 69.56 & 80.85 \\
\hline & II Year & 71.22 & 74.66 & 76.89 & 103.22 & 75.78 & 89.67 & 92.89 & 77.66 & 70.33 & 91.22 & 70.89 & 81.31 \\
\hline \multirow[t]{2}{*}{ American Beauty } & I Year & 71.67 & 76.56 & 100.44 & 76.89 & 89.33 & 92.56 & 71.89 & 75.56 & 103.56 & 72.22 & 72.11 & 82.07 \\
\hline & II Year & 71.56 & 75.44 & 98.22 & 77.00 & 87.44 & 92.67 & 71.78 & 75.00 & 103.78 & 72.45 & 73.33 & 81.70 \\
\hline \multirow[t]{2}{*}{ Chandni } & I Year & 71.78 & 100.22 & 71.44 & 92.22 & 103.22 & 71.78 & 71.22 & 91.78 & 71.22 & - & - & 67.72 \\
\hline & II Year & 71.00 & 97.78 & 71.45 & 93.33 & 103.67 & 73.22 & 71.11 & 92.67 & 70.56 & - & - & 67.71 \\
\hline \multirow[t]{2}{*}{ Red beauty } & I Year & 102.78 & 71.22 & 91.89 & 102.67 & 71.33 & 71.33 & 91.33 & 72.33 & 72.22 & 72.44 & 102.33 & 83.81 \\
\hline & II Year & 102.89 & 72.11 & 92.00 & 103.22 & 71.45 & 71.11 & 92.00 & 73.00 & 73.00 & 71.44 & 102.00 & 84.02 \\
\hline \multirow[t]{2}{*}{ Punjab Morning } & I Year & 71.44 & 91.56 & 103.44 & 71.11 & 71.56 & 90.89 & 72.56 & 71.78 & - & - & - & 58.58 \\
\hline & II Year & 71.67 & 91.78 & 103.89 & 71.00 & 72.34 & 91.11 & 73.44 & 72.33 & - & - & - & 58.87 \\
\hline \multirow[t]{2}{*}{ White Prosperity } & I Year & 90.78 & 103.33 & 71.67 & 71.78 & 91.22 & 72.89 & 71.89 & 72.78 & 102.44 & 71.44 & 90.22 & 82.77 \\
\hline & II Year & 90.67 & 103.67 & 71.00 & 72.33 & 91.33 & 74.22 & 71.67 & 73.44 & 102.44 & 71.67 & 89.78 & 82.93 \\
\hline \multirow[t]{2}{*}{ Jester } & I Year & 101.78 & 71.89 & 72.22 & 90.78 & 74.11 & 72.67 & 71.22 & 101.67 & 70.78 & 90.22 & 103.11 & 83.68 \\
\hline & II Year & 99.78 & 72.56 & 72.11 & 91.34 & 75.00 & 73.00 & 70.33 & 101.44 & 70.33 & 89.78 & - & 74.15 \\
\hline \multirow[t]{2}{*}{ Srijana } & I Year & 70.78 & 72.44 & 90.44 & 73.89 & 72.56 & 71.22 & 102.11 & 70.67 & 90.67 & 103.56 & 70.89 & 80.84 \\
\hline & II Year & 70.67 & 73.00 & 90.55 & 74.11 & 72.78 & 71.78 & 102.45 & 70.33 & 90.22 & 103.78 & - & 74.52 \\
\hline \multirow[t]{2}{*}{ Psittacinous Hybrid } & I Year & 72.33 & 90.67 & 74.56 & 72.44 & 70.22 & 101.56 & 70.44 & 90.22 & - & - & - & 58.40 \\
\hline & II Year & 72.33 & 90.55 & 74.55 & 72.33 & 70.00 & - & - & - & - & - & - & 34.52 \\
\hline \multirow[t]{2}{*}{ Priscilla } & I Year & 91.22 & 74.22 & 72.44 & 72.33 & 102.67 & 71.78 & 91.56 & 102.56 & 71.44 & 71.67 & 91.56 & 83.04 \\
\hline & II Year & 90.56 & 75.11 & 73.00 & 71.67 & 102.67 & 71.00 & 91.33 & 102.78 & 71.67 & 72.00 & 91.33 & 83.01 \\
\hline \multirow[t]{2}{*}{ Mean } & I Year & 81.40 & 82.60 & 82.62 & 82.70 & 82.23 & 80.55 & 80.51 & 82.76 & 65.26 & 57.32 & 59.98 & \\
\hline & IIYear & 81.23 & 82.67 & 82.37 & 82.96 & 82.24 & 70.78 & 73.70 & 73.87 & 65.23 & 57.23 & 42.73 & \\
\hline C.D. (0.05) & & I Year & II Year & & & & & & & & & & \\
\hline Treatment & & 0.53 & 0.53 & & & & & & & & & & \\
\hline Variety & & 0.55 & 0.55 & & & & & & & & & & \\
\hline T reatment $\times$ Variety & & 1.75 & 1.75 & & & & & & & & & & \\
\hline
\end{tabular}

Table.4 Effect of gamma irradiation on number of florets per spike in different varieties of gladiolus

\begin{tabular}{|c|c|c|c|c|c|c|c|c|c|c|c|c|c|}
\hline Varieties & reatment & control & $0.5 \mathrm{Kr}$ & $1.0 \mathrm{Kr}$ & $1.5 \mathrm{Kr}$ & $2.0 \mathrm{Kr}$ & $2.5 \mathrm{Kr}$ & $3.0 \mathrm{Kr}$ & $3.5 \mathrm{Kr}$ & $4.0 \mathrm{Kr}$ & $4.5 \mathrm{Kr}$ & $5.0 \mathrm{Kr}$ & Mean \\
\hline \multirow[t]{2}{*}{ Candyman Rose } & I Year & 14.67 & 14.22 & 10.33 & 13.33 & 12.89 & 13.00 & 14.11 & 12.44 & 13.33 & 14.22 & 14.33 & 13.35 \\
\hline & II Year & 14.89 & 13.78 & 10.89 & 13.22 & 13.00 & 13.22 & 13.89 & 13.11 & 13.33 & 14.00 & 14.22 & 13.41 \\
\hline \multirow[t]{2}{*}{ American Beauty } & I Year & 13.33 & 11.33 & 13.78 & 12.89 & 13.11 & 14.11 & 12.44 & 13.11 & 14.45 & 14.67 & 13.78 & 13.36 \\
\hline & II Year & 13.22 & 12.67 & 14.34 & 12.66 & 13.22 & 14.44 & 12.33 & 12.78 & 14.56 & 14.89 & 13.67 & 13.53 \\
\hline \multirow[t]{2}{*}{ Chandni } & I Year & 12.00 & 14.00 & 13.33 & 13.67 & 12.22 & 13.67 & 13.22 & 13.22 & 14.00 & 0.00 & 0.00 & 10.85 \\
\hline & II Year & 11.45 & 14.22 & 13.89 & 13.78 & 11.00 & 14.00 & 13.89 & 12.67 & 13.67 & 0.00 & 0.00 & 10.78 \\
\hline \multirow[t]{2}{*}{ Red beauty } & I Year & 14.56 & 14.56 & 13.45 & 12.44 & 13.89 & 14.56 & 14.67 & 13.78 & 11.89 & 13.89 & 13.44 & 13.74 \\
\hline & II Year & 14.78 & 14.78 & 13.78 & 12.67 & 13.67 & 14.44 & 14.44 & 13.44 & 12.33 & 14.33 & 13.22 & 13.81 \\
\hline \multirow[t]{2}{*}{ Punjab Morning } & I Year & 13.56 & 12.00 & 14.11 & 13.55 & 12.89 & 14.00 & 13.00 & 14.67 & 0.00 & 0.00 & 0.00 & 9.80 \\
\hline & II Year & 13.44 & 12.33 & 14.33 & 13.22 & 13.00 & 14.33 & 12.67 & 14.44 & 0.00 & 0.00 & 0.00 & 9.80 \\
\hline \multirow[t]{2}{*}{ White Prosperity } & I Year & 14.00 & 14.67 & 14.11 & 13.67 & 11.89 & 14.33 & 13.67 & 13.44 & 11.89 & 10.11 & 13.22 & 13.18 \\
\hline & II Year & 14.22 & 14.67 & 14.67 & 13.67 & 10.89 & 14.22 & 14.00 & 13.67 & 10.89 & 9.89 & 13.22 & 13.09 \\
\hline \multirow[t]{2}{*}{ Jester } & I Year & 13.00 & 12.78 & 13.89 & 12.78 & 13.11 & 14.33 & 13.89 & 13.56 & 10.78 & 13.33 & 13.55 & 13.18 \\
\hline & II Year & 12.67 & 12.89 & 13.89 & 12.45 & 13.11 & 14.33 & 14.33 & 13.33 & 10.00 & 13.33 & 0.00 & 11.85 \\
\hline \multirow[t]{2}{*}{ Srijana } & I Year & 12.67 & 13.78 & 14.33 & 12.33 & 13.44 & 13.33 & 14.78 & 13.00 & 13.11 & 14.56 & 13.44 & 13.52 \\
\hline & II Year & 12.78 & 13.78 & 14.22 & 12.67 & 13.22 & 14.00 & 14.67 & 13.22 & 13.22 & 14.78 & 0.00 & 12.41 \\
\hline \multirow[t]{2}{*}{ Psittacinous Hybrid } & I Year & 12.89 & 13.89 & 12.89 & 14.22 & 12.67 & 13.44 & 13.78 & 14.33 & 0.00 & 0.00 & 0.00 & 9.83 \\
\hline & II Year & 13.00 & 14.33 & 12.67 & 14.22 & 13.11 & 0.00 & 0.00 & 0.00 & 0.00 & 0.00 & 0.00 & 6.12 \\
\hline \multirow[t]{2}{*}{ Priscilla } & I Year & 13.22 & 12.56 & 14.11 & 12.44 & 12.78 & 13.78 & 12.89 & 14.56 & 14.78 & 13.78 & 11.44 & 13.30 \\
\hline & II Year & 13.22 & 12.78 & 14.55 & 12.22 & 12.45 & 13.55 & 12.89 & 14.78 & 14.78 & 13.78 & 10.45 & 13.22 \\
\hline \multirow[t]{2}{*}{ Mean } & I Year & 13.39 & 13.38 & 13.43 & 13.13 & 12.89 & 13.86 & 13.65 & 13.61 & 10.42 & 9.46 & 9.32 & 13.39 \\
\hline & IIYear & 13.37 & 13.62 & 13.72 & 13.08 & 12.67 & 12.66 & 12.31 & 12.14 & 10.28 & 9.50 & 6.48 & 13.37 \\
\hline C.D. (0.05) & & I Year & IIYear & & & & & & & & & & \\
\hline Treatment & & 0.23 & 0.24 & & & & & & & & & & \\
\hline Variety & & 0.24 & 0.25 & & & & & & & & & & \\
\hline T reatment $\times$ Variety & & 0.76 & 0.79 & & & & & & & & & & \\
\hline
\end{tabular}


Present results were also in accordance with Cantor et al., (2002) who observed that gamma doses increased root and shoot length, which probably absorb more nutrient and improved photosynthesis and ultimately resulted in early spike emergence and flowering. Rather and John (2000) also studied days to floret emergence in Dutch iris. Some doses of gamma rays resulted in early floret emergence; however, difference was not significant to the control.

In respect of varieties data presented in Table 3 exhibited significant effect on days taken to flowering during both years of investigation. Days taken to flowering were recorded highest in cv. Red Beauty during both the year of investigation. Earliest flowering was recorded with interaction of control with $\mathrm{cv}$. Candyman Rose (69.44 days) during first year while during second year interaction of gamma dose at $2.0 \mathrm{kr}$ with $\mathrm{cv}$. Psittacinous Hybrid (70.00 days) resulted in earliest flowering. Present findings were in agreement with that of Seilleur (1975), who irradiated corms of gladiolus and observed that corms treated with lower doses resulted in early flowering. Similar observation has also been made by Misra et al., (2009) who got early bud initiation in chrysanthemum when various gamma doses were applied. The present findings were also in line for days to flowering in gladiolus cv. Sylvia and Eurovision (Srivastava et al., 2007). They recorded early flowering with 20 Gy and 40 Gy in comparison to control on days to flowering. Similar type of stimulatory effect was observed earlier by Misra and Bajpai (1983) with $2 \mathrm{kR}$ and $3 \mathrm{kR}$ doses in nine varieties of gladiolus that used for study and by Dhaduk (1992) with $3 \mathrm{kR}$ and $5 \mathrm{kR}$ in four varieties of gladiolus. Raghava et al., (1988) and Negi et al., (1983) noted that the flowering was delayed significantly at $5 \mathrm{kR}$ treatment in various varieties used in their studies. The present findings are also in line with the observations of Mahure et al., (2010) observed that lower dose proved favourable for early flowering in chrysanthemum.

Number of florets per spike reduced due to application of gamma doses (Table 4), as doses increased and higher doses of gamma rays resulted in minimum number of florets per spike. During first year maximum number of floret was recorded with $2.5 \mathrm{kr}$ (13.86) dose of gamma irradiation. However, during second year maximum number of florets per spike were registered with $1.0 \mathrm{kr}$ dose of gamma irradiation which was at par with 0.5 $\mathrm{kr}$, control and $1.5 \mathrm{kr}$ and significant to other gamma irradiation doses on number of florets per spike, whereas these treatments were significant to the higher doses of gamma irradiation. Due to interaction of gamma doses and different varieties number of flowers/spike found significant. Treatment combination of $4.5 \mathrm{kr}$ with cv. White Prosperity resulted in minimum number of florets per spike during both the year of investigation. Present findings are in conformity with several workers who recorded positive response of gamma irradiation at lower doses and higher doses were found detrimental and showed negative response. In a study Venkatchalan and Jayabalan (1992) observed that the number of flowers in zinnia increased with the lower dose of gamma irradiation from 2.5 to $5 \mathrm{kr}$ and decreased thereafter at higher doses of 7.5 $\mathrm{kr}$ to $12.5 \mathrm{kr}$. Kole and Meher (2005) observed increase in the flower number at lower doses of gamma irradiation, whereas, number of flower reduced drastically at higher dose of gamma rays in zinnia. They further observed that due to application of gamma doses percentage of double flowers increased significantly compared to control. Arnold et al., (1998) stated that number of petals increased with application of gamma doses in two varieties, i e Potluck and Dark Red Mountie, whereas, it decreases in other 
two varieties Blood Red and Mountie due to gamma doses at 50, 100 and $200 \mathrm{~Gy}$. They further stated that dose response relationship often showed erratic results because gamma rays photons may miss the targets necessary to generate mutation and radio sensitivity depends on the variety.

\section{References}

Arnold, N.P., Barthakur, N.N. and Tanguay, M. 1998. Mutagenic effects of acute gamma irradiation on miniature roses: Target theory approach. Horticulture Science, 33: 127-29.

Awad, A.R.E. and Elbahr, K. 1986. Growth regulators and gamma irradiation treatments affecting the sprouting and endogenous harmones in gladiolus. Acta-Horticulture, 177 (2): 612-615.

Cantor, M., Pop, I. and Korosfoy, S. 2002. Studies concerning the effect of gamma radiation and magnetic field exposure on gladiolus. Journal of Central European Agriculture, 3(4): 277-284.

Dhaduk, B. K. 1992. Induction of mutation in garden gladiolus (Gladiolus L.) by gamma rays. Ph.D. Thesis. Submitted to IARI, New Delhi.

Karki, K. and Srivastava, R. 2010. Effect of gamma irradiation in gladiolus (Gladiolus grandiflorus L.). Pantnagar Journal of Research, 8(1): 55-63.

Kole, P. C. and Meher, S. K. 2005. Effect of gamma rays of some quantitative and qualitative characters in Zinnia elegans N.J. Jacguin in M1 generation. Journal of Ornamental Horticulture, 8 (4): 303 5.

Mahure, H.R., Choudhary, M.L., Prasad, K.V. and Singh, S.K. 2010. Mutation in chrysanthemum through gamma irradiation. Indian Journal of Horticulture, 67: 356-58.

Misra, P., Banerji, B.K. and Kumari, A. 2009. Effect of gamma irradiation on
Chrysanthemum cultivar 'Pooja' with particular reference to induction of somatic mutation in flower colour and form. Journal of Ornamental Horticulture, 12(3): 213-216.

Misra, R.L. and Bajpai, P.N. (1983). Mutational studies in gladioli (Gladiolus L.): Effect of physical and chemical mutagens sprouting and survival of corms. Haryana Journal of Horticulture Science, 12(1-2): 16-19.

Negi, S. I.; Raghava, S. P. S. and Sharma, T. V. R. S. 1983. Induction of mutations in gladiolus by gamma rays, abstract of contributed paper XV International Cong Tess of Genetics, New Delhi, Dec. 12-27 Part II. Session C-IVD to VIID: 480.

Panse, V. J. and Sukhatme, P. V. 1967. Statistical methods for Agricultural Workers, Published by I. C. A. R., New Delhi.

Patil, S. D. 2014. Induction of mutation in commercial varieties of gladiolus using physical mutagen $\mathrm{CO}-60$ gamma rays. International Journal of Advance Research and Biological Sciences, 1(6): 15-20.

Patil, S. D. and Dhaduk, B.K. 2009. Effect of gamma radiation on vegetative and floral characters of commercial varieties of gladiolus (Gladiolus hybrida L.). Journal of Ornamental Horticulture, 12(4): 232-238.

Pranom, P., Sangtham, K. and Orwan, M. 1986. Production of gladiolus. Effect of gamma irradiation on certain characteristics of gladiolus var. Spic and Span, Norwich Canary. Research and Development Institute. Research Reports. Kasestsart University (Thailand), 85.

Raghava, S.P.S., Negi, S.S., Sharma, T.V.R.S. and Balakrishnan, K.A. 1988. Gamma ray induced mutants in Gladiolus. Journal of Nuclear Agriculture and 
Biology, 17(1): 5-10.

Rather, Z. A. and Jhon, A. Q. 2000. Effect of ${ }^{60}$ Co gamma rays on Dutch iris. Journal of Ornamental Horticulture, 3 (2): 714.

Seilleur P. 1975. Effects of irradiation of gladiolus corms on the physiological behaviour of plants derived from them. Bulleten des Researches Agronomiques de Gembloux, 10 (3): 291-306.

Singh, A.K. 2006. Flower Crops Cultivation and Management. New India Publishing Agency, New Delhi, India, pp. 97-104.

Srivastava, P.; Singh, R. P. and Tripathi, V. R. 2007. Response of gamma radiation on vegetative and floral characters of gladiolus. J. Ornam. Hort. 10 (2): 135136.

Venkatchalam, P. and Jayabalan, N. 1992. Analysis of leaf protein in gamma rays induced mutants of zinnia. Crop Improvement, 19: 97-9.

\section{How to cite this article:}

Kuldeep Sahariya, R.A. Kaushik, Rashid Khan and Deepak Sarolia. 2017. Influence of Gamma Irradiation on Flowering of Gladiolus (Gladiolus hybrida L.). Int.J.Curr.Microbiol.App.Sci. 6(11): 1362-1368. doi: https://doi.org/10.20546/ijcmas.2017.611.162 